\title{
水産養殖産地における自発的販売組織の展開と産地再編
}

一愛媛県宇和島市蒋渕地区の調査結果から一

\author{
矢野 邦子 1$) *$ ・香月 敏孝 ${ }^{2)} \cdot$ 山藤 篤 2
}

\section{Development of Autonomous Sales Organization for Restructuring Aquaculture Production Area: A Case Study of Komobuchi, Uwajima City, Ehime Prefecture}

\author{
Kuniko Yano $^{1) *}$, Toshitaka Katsuki²) \& Atsushi Yamafuji2)
}

This study focuses on the marketing techniques of aquaculture, which are expected to contribute to employment creation and enhance regional economic activities in the aquaculture production areas experiencing significant depopulation. We examined the process of sales-organization development through a case study of Komobuchi, which is located in the south of Ehime. The main results are as follows: 1) The new idea related to marketing was not created without a sense of the impending crisis of residency; therefore, the autonomous sales organization in this area was structured for halting the decline in local resident numbers. 2) It was found effective to let immigrants be the main customers in sales promotion; sales have tripled since. 3) More fascinations characteristics of this district in solving the problem of product commercialization were found through partnership with external experts.

キーワード : 養殖漁業, 農商工連携, 地域活性化, 商品開発, 地域力, ソーシャルビジネス

1. はじめに

(1) 研究の背景, 目的と課題

全国には住民の半数近くが 65 歳以上で占められ る限界集落と呼ばれる地域が多数存在している。 こ れらの地域として農山村が注目されることが多いが, 漁村もその例外ではない. 漁業生産の振興策として 養殖漁業の取組が進められたことは周知のことであ るが, 養殖漁業は限られた高級魚の生産に特化して いるため生産過剩を引き起こしやすい，現状では， 多くの養殖産地が過剩生産による価格低下に見舞わ れて打り, かかる状沉の下で, 産地再編に向けた取 り組みが必要となっている.

本稿は，こうした漁業をめぐる問題背景を踏まえ て養殖産地に打いて従来型の加工を施さない原体の
ままの鮮魚販売から脱し，商品開発と新たな販売方 法の開拓に取り組んでいる自発的組織を対象にして, その活動経過を追跡しながら, 活動の特徴を明らか にするとともに, 今後の展開可能性について考察す ることを目的としている.

こらした農山漁村地域再生に関する既存の研究 は, これまで農林業を対象とする研究 (小田切, 2011 ; 宮崎, 2015）が主であり, 漁業分野において はあまり多くない. 少ない漁業分野の研究の中で, 漁協女性部による地域再生に焦点をあてた研究（天 野他，2015）があるが，自立後の組織実態は明らか にしているものの，自立に至る経過の分析は十分之 はいえない．

ここでは，漁協の提示する価格で販売することに

\footnotetext{
1) 愛媛大学大学院連合農学研究科; The United Graduate School of Agricultural Sciences, Ehime University

2) 愛媛大学農学部; Faculty of Agriculture, Ehime University

*E-mail: hana925@nifty.com

(C)地域農林経済学会
} 
よって利益のない出荷も多く, 養殖魚の生産を辞め ていく人が続いた。 そのため蒋㴊を出て仕事を求め こうした人口の流失が課題となったことから, 自ら 販売組織を作ることによって, その解決策を見出し た点に特徵がある. (図 1 参照) 本稿では, 自立化に 向けた取組過程に注目した分析を行っていくことに する.

\section{（2）調査地域の概要と調查方法}

愛媛県はマダイの養殖日本一を誇る産地である. 図 2 に示したよらに, 養殖生産量が平成 11 年まで 急増した後, 単価は年々下落傾向を辿り近年ではピ 一ク時の打よそ 6 割程度にまで落ち込んでいる. 養 殖業の普及は生産過剩を生み出したといえる.

本研究の調查対象である愛媛県宇和島市蒋㴊地区 は愛媛県の南部に位置し入江と半島のリアス式海岸

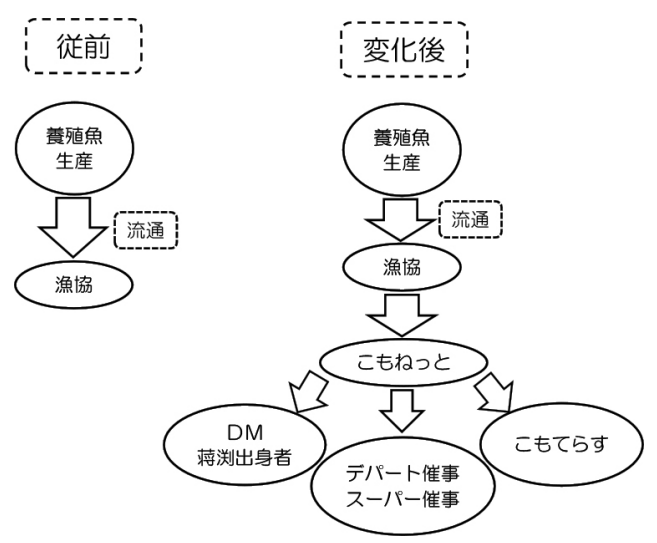

図 1. 流通, 出荷状況，販路の変化. 資料 : 筆者作成.

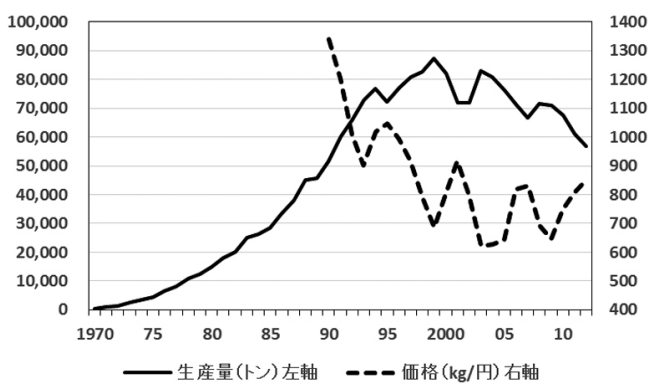

図 2. 養殖マダイの生産と価格の推移.

資料：農林水産省 (2013).
で宇和海に突き出した三浦半島の先端にある，起伏 が多い地形で主要な産業としてマダイを中心に，力 ンパチ, 岩牡蠣, 真珠等の養殖が盛んである.

国勢調査によると同地区の人口は，平成 7 年に 566 人（うち 65 歳以上 228 人）であったが，以降 5 年ごとに 528 人（同 219 人), 454 人（同 192 人）と 減少し, 平成 22 年には 381 人（同 161 人）となっ ている. 平成 12 年までは人口は比較的維持されてい たものの，その後は養殖業の不振と期を同じくして 人口減少が止まらない状況となっている.

平成 22 年の就業者 132 人のらち, 養殖を中心と する漁業従事者は 75 人をも占めて扣り, 人口減少と 高齢化が進行する下，養殖産地の再編は地区の再生 にとって極めて重要な課題であることがわかる.

以下, 本稿では上の課題を明らかにするために, 現地での実態調査に基づき養殖産地再編の過程を整 理していく.この産地の取組の特徵は, 養殖魚の販 売先をこの地区から離れていった住民に求めること から始め, 付加価値のある加工食品の生産を積極的 に行って雇用創出を実現させた点にある.このため, こらした活動成果をもたらした商品開発の取組と販 路の変化に焦点を当てていく.

\section{2. 自発的販売組織の形成と展開}

\section{（1）企業組合こもねっとの設立と背景・経緯}

酒を酌久交わすお講という場で地域活性化の為に 何ができるのか, 漁業者と漁業以外の地元住民は話 し合う機会を重㸚た，子供たちに残せる故郷とは何 かを模索して行った。

地域力の活用と住民との繋がりを大切にし「蒋㴊 を離れた人たちにも故郷を思ら気持ちで地域活性化 に参加してもらいたい」といら気持ちが生まれた。

養殖魚の価格の低迷から養殖魚の生産量も年々減 少し，地域に仕事が無くなれば働き手は外へ流れて いくといら悪循環を止めるため，それまで行ってい なかった加工品の開発販売によって, 新たな仕事を 創出する地域力経営 ${ }^{1}$ を目指し限界集落から魅力あ る地域づくりを提案しょうと, 平成 16 年任意団体 「こもねっと」を漁業者 3 名で立ち上げた.

最初の取り組みとして, 豊かな海を守り子供たち の為に残そらと蒋滜湾活性化プロジェクトを立ち上 げた. ガンガゼの駆除と母藻を岩礁に付着させ生育 
を目指す取り組みを行った，ガンガゼと呼ばれる食 用にならないウ二は海草の新芽を好み食い荒らし魚 場を荒らしていため蒋㴊湾の海中の岩礁が石灰化し 海草が極端に減少していた．地元住民からは「意味 のないことだ」「とらてい無理だ」といら反対の声も あがった，有志達は自己資金で取り組み続けた。平 成 21 年には蒋㴊から都会へ移り住んだ人へ向けた蒋 㴊の情報誌「コモマガ」の制作に取り組んだ.A4の 用紙 2 枚程度にカラー印刷で小学校の運動会の様子 や地域の技祭りの様子, 蒋㴊活性化プロジェクトの 活動の成果を載せ，そこに地元で取れた水産物や加 工食品を揭載し販売を行った.

地元に残る家族や親戚を一軒一軒周り, 転居先の 住所を聞いて 2,500 人を超えるリストになり全戸へ 郵送した。懐かしさと地元を応援しょう，故郷が消 滅してほしくないといら思から，送付数の $1 / 3$ の人 たちが購入した。蒋㴊から都会へ移り住んだ人たち を優良顧客と見なして行動したといら産地展開の仕 方が興味深い.

この「コモマガ」での収益の一部は綺麗な海を守 る取組蒋㴊活性化プロジェクトの資金にあてられた。

平成 25 年に対外的信用を得る為に任意団体から 企業組合こも称っと（以下，こも和っと）飞再編し 産地展開を積極的に進めることになる. 組合員 6 名 と准組合員 2 名そのらち販売強化の為, 専従従業員 を1名雇用した。
（2）問題解決の為の商品開発とイノベーション

「コモマガ」に揭載された販売商品（表 1 参照）は 当初，マダイやカンパチなど大型魚を丸ごと 1 匹を 主に販売するものだった，次いで，鮮魚とあわせて 一夜干しやフィレ加工品も加えたが，これも半身な ぞ大型のものが主だった．核家族化や孤食化を背景 に大型魚を家庭で調理する需要が無くなってきてい る状況を鑑及年々売り上げが伸び悩んだことから， 平成 24 年に魚をさばかなくても手軽に食べられる, 1 人分のマダイ切り身の一夜干しを作り始めた。

真鯛の一夜干しは家庭用，贈答用などにも人気が あり生産が増えて行ったが，これに伴い加工時に出 る大量のアラの廃棄がこも㸚っとの加工部門から問 題になり，捨てずに商品にすることはできないかと 考えた. 平成 25 年度えひめ農商工連携ファンド事業 助成金 3 を活用し当ファンドが目的としている，問 題解決の為の未利用資源を活かした商品開発に取り 組むこととなる．地域の中だけの活動範囲から広が りはじめ，ここからイノベーションが起きる。

イノベーションとは一見関係なさそらな事柄を結 びつける思考やこれまでの産業のありかたを覆すよ らなものを指し，漁業者が地域住民と繋がって新し い組織を作りだし企業組合を作り，図 3 の示す通り 県内の異業種との協働で作り上げた新しい取り組み を指す。ソーシャルビジネスに繋がっていく。

ソーシャルビジネスとは（根岸，2014）によれ

表 1. 売上の推移とコモマガ販売アイテム数. 単位（売上 : 千円，アイテム数 : 個)

\begin{tabular}{|c|c|c|c|c|c|c|c|c|}
\hline \multirow{3}{*}{ 年 } & \multirow{3}{*}{ 売上合計 } & \multicolumn{6}{|c|}{ ダイレクトメールによる販売アイテム数 } & \multirow{3}{*}{ 販売等扣もな出来事 } \\
\hline & & \multirow{2}{*}{ 鮮魚 } & \multicolumn{4}{|c|}{ 加工 } & \multirow{2}{*}{ その他 } & \\
\hline & & & 一夜干し & 開き & セット & 未利用資源 & & \\
\hline 平成 21 年 & 2,724 & 9 & 1 & 0 & 1 & 0 & 3 & ユモマガでの販売開始 2,500 人 \\
\hline 22 & 2,992 & 9 & 1 & 0 & 3 & 0 & 10 & 県内の道の駅のイベント出店 \\
\hline 23 & 3,967 & 9 & 4 & 3 & 2 & 0 & 13 & 大阪今里郵便局で海産物販売 \\
\hline 24 & 4,952 & 18 & 10 & 0 & 2 & 0 & 12 & 首都圏の催事での販売開始 \\
\hline 25 & 13,380 & 11 & 12 & 3 & 1 & 3 & 10 & $\begin{array}{c}\text { 農商工連携で商品開発を行う } \\
\text { 企業組合へ組織再編 }\end{array}$ \\
\hline 26 & 13,523 & 10 & 5 & 2 & 0 & 11 & 6 & $\begin{array}{c}\text { レトルトグランプリ金賞を受賞 } \\
\text { NHKで取り上げられる } \\
\text { 発送者リストが, } 4,000 \text { 人に }\end{array}$ \\
\hline
\end{tabular}

資料：平成 21 年から 26 年のコモマガより.

1）七ットは加工食品等の複合販売.

2）未利用資源は平成 25 年農商工連携開発商品. 
ば，社会問題の解決を目的として収益事業に取り組 む事業体のことを指す。ここで言う社会問題とは, 先にも示した養殖魚の価格低迷により養殖魚の売り 上げも減少し, 地域に仕事が無くなり人口流失が顕 著になっていることを指す，真鯛の一夜干しを作る 時に出る大量のアラを使った商品開発を行らことが, ここで言う社会問題解決の為の商品開発, ソーシャ ルビジネスとなった.

生産から消費に至る全てを事業として構築し，材 料の調達, 加工, 流通システムを全てこも齐っとで 行らことを試みることとなった。

マーケティングの手法としてターゲットを蒋洖出 身者の 35 歳女性で東京で仕事を持ち夫と子供 1 人 と 3 人暮らし, 多忙な毎日でも健康に気を付忖てい て手早く簡単に美味しい料理を切望する人と想定し た. 商品開発をするに当たり架空の 1 人の人間をイ メージしその人が買いたいと思うものは何かと言う 論点で作り上げる. その結果, 予想していたターゲ ットからずれて販路が広がることも多いが，初めか ら老若男女, 多くの地域で売れるような商品開発議 論は商品作りの目的や販路が定まらないからだ.

イメージしたターゲットに向けて，簡単調理，健 康，無添加，長期保存，などを実現するためのレト ルト食品の開発とテーマを決め, 商品開発を始めた. まず, こも㸚っとは問題の大量の廃棄物であったマ ダイの骨に圧力をかけ柔らかくしてペースト状にし た．色と滑らかさと骨から出る旨味をそのまま生か すため, 添加物の無い家庭の味わいの残るベシャメ ルソース ${ }^{4}$ に加光仕上げた. 何度も試作を重ね, 地 元の主婦などの意見も取り入れ「真鯛のベシャメル ソース」が完成した.

販売ターダットと類似する子育て中の母親に向け た試食会を開催し意見をもらった。「旨味の成分が添 加物でなく真鯛の骨からの旨味と知って体に良い食 べ物と感じた」「今までに無かった商品で， あったら いいなと思える商品だ」と言う好意見があった反面, 「マダイと聞いて值段が気になる」「高すぎると健康 によくても日常的には買いにくい」といら声も あった。

従来，生産者が商品開発をするにあたり外部企業 に専門的な部分を外注し丸投げしてしまう形が多か ったが，全て自分たちの意見を反映させ作りだすこ

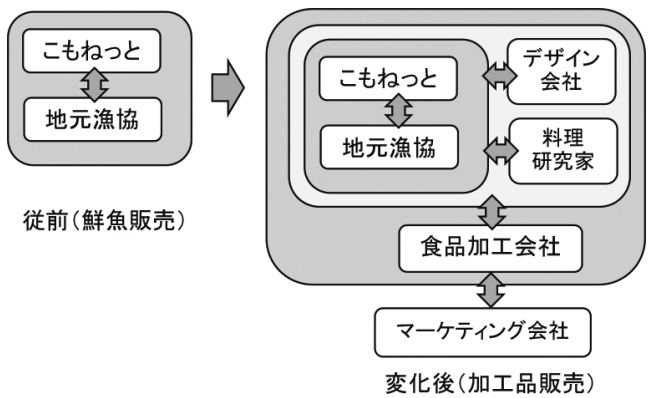

図 3.こも初とを中心とする商品開発・販売に向 忊た事業者連携図。

資料：筆者作成.

とにより潜在能力を呼び起こし, 地域力に自信が湧 き何のための商品作りかを自覚して行った.

それぞれの役割分担と連携により商品開発が行わ れた。こうしたこも初っとを中心とする商品開発の 事業者間の連携状沉を従前と比較して示したのが, 図 3 である。

この商品に並行して，その他にも商品開発が行わ れた. マダイの一夜干しの売り上げを伸ばすために, 特殊なフィルムにマダイの一夜干しとソースを入れ 真空パックにした．野菜を煮込んだソース，カポナ 一タやごま油の香りのいい中華味，きのことバタ一 を詰めたきのこバタ一味など手軽に家庭でマダイを 味わってもら打うと「打うちでカフェごはん」と名 付けて 3 種類を発売した.

作業工程は養殖魚を仕入れ直後にさばき，乾燥庫 内で一晚低温乾燥熟成させ，急速冷凍する。その素 材を使ってそれぞれの味付忷作業を行い真空パック にしていく。レンジで 2 分 30 秒加熱するだけで本 格的なマダイ料理が食べられる 1 品に仕上げた．好 評を得て平成 25 年度の売り上げに貢献していく.

今まで述べた農商工連携の取り組みは企業組合と なり対外的な信用を得たことから国の補助金が活用 できた。自発的に自分たちの抱える問題を解決しょ らと第一義に行動した結果，そこに企業としての收 益が伴った。 まさに社会問題の解決を目的とした収 益事業に取り組んだその結果といえる. 


\section{3. 産地再編の展望}

\section{(1) 売り上げの推移}

平成 21 年コモマガを中心として販売を強化し，同 年ホームページを活用しネット販売も始めた。 平成 24 年からは東京や大阪などの催事の出店や販路拡大 に積極的に動いた。企業間取引も次第に増光，ホテ ルの OEM の商品制作も手掛けるようになった。

平成 26 年 3 月に FOODEX JAPAN2014 5 で「真鯛 のベシャメルソース」が金賞を取り同年 NHK 佂は よら日本等のメディアに取り上げられたこともあり， 注文が殺到して一時的にさばききれない程の状況に なった，企業・商品の認知度向上・生産設備の増強 により売り上げは平成 24 年度 4,952 千円から平成 25 年度では 13,293 千円， 26 年度は 13,523 千円と増 加している.（売り上げの推移は前掲表 1 を参照)

平成 25 年には前述したマダイの一夜干しの加工 品「おうち de カフェごはん」の新商品の販売が開始 されたことも増額の要因となった。平成 25 年 11 月 から郵便局の拈歳暮商品として全国の郵便局でチラ シが配布され「おらち de カフェごはん」6 個入り 4,500 円が 300 セット完売した.

13,000 千円は，売り上額としては十分とは言えな いが，こうした規模に到達したことで，加工・販売 に専念できる職員の雇用が可能となった，従前以上 に商品加工の増産や販売のアイテムを増やすことに 対応できる体制が整ったことになり，今後の展開に 弾みがついた。

\section{（2）情報発信基地の創設}

産地展開の次なる取り組みとして情報発信基地の 拠点の必要性から「らみの家こもてらす」の創設に 取り組むこととなる。産地を知り, 提供した食品の 付加価值をわかってもら打うと, 地元に足を運ぶ拠 点を作ることを決めた。

平成 26 年度地域経済循環創造事業交付金を利用 乙平成 27 年 3 月, 真珠養殖の倉庫を賃貸して大規 模に改装し，観光交流施設「らみの家こもてらす」 （以下，こもてらす）を完成させた. 全国へ蒋㴊の魅 力を発信し蒋㴊出身者以外のファンを増やすための 次のステージへの布石でもあった.

その場所には海に突き出すような広いデッキを作 った。 丸太で椅子を作り蒋㴊湾が一望でき, 日本一 短い細木運河も見渡せる絶景を堪能できる拠点を作
った．この場所に加工場も移動し併設し，ここで商 品は作られていると言う付加価值を付けたいと考光 た．地元の海産物を味わえるカフェも併設し，マダ イの一夜干しを使ったランチや海鮮バーベキューな ぞも楽しめるメニューが揃った．飲食店が 1 軒も無 い地域であり夏はビヤガーデンの開催や，1 日 1 組 のこもてらすの結婚式なぞも企画した.

情報発信基地こもてらすの創設によって，地域住 民の意識改革も起きている。誰も来ない田舎の漁村 が魅力的な場へと認識されはじめている。

\section{4. おわりに}

蒋㴊地区のケースは，このままでは限界集落とな り消滅の危機から逃れるためにはどらしたらいいの か地域住民の苦悩と地域内外のアイディアの融合で 成功した再生の一考察として興味深い展開である。

新しいマダイの食べ方提案や商品開発が起爆剂と なり，地域の人たちの意識も変わっていった，それ は先に記した単なる商品開発ではなく社会問題解決 の為の商品開発であり, 地域外と地域内の力を上手 く融合させ，打互いの得手を地域活性化の為に発揮 できた一例であると言える。ともすると，農山漁村 の商品開発はプロダクトアウト 5 に陥りがちだが, マーケットイン 6 の考方方に基づく売り先も見据光 た商品開発となった。

蒋㴊の挑戦の特徵は人口流失を単に損失と捉える だけでなく，それをビジネスチャンスと捉え優良顧 客とした取り組みにある。「懐かしい故郷を応援す る」と言う気持を起こさせるといら販売戦略を立て, 蒋㴊を出て行った人を顧客にするといら新しい発想 を生み出した. 平成 26 年にはコモマガの発送者リス トが 4,000 人になった。 こも初っとの作る商品の販 売は地元に利益を落とすための取組であって，こも ねっとだけが儲かればいいといら仕組みではない。 素材は漁協を通し地元で購入することにより売り手 側の利益が出る価格とした。扮のずと販売価格も割 高になる.しかし，地元にいる時には価値を見いた せなかったありふ水た食材も地域を離れてみると， その商品価值を再認識し值段が高くても買いたいと 思わせるものとなった。

地元を離孔た蒋㴊出身者が全国で蒋㴊出身者以外 の人へのロコミや多くの手段を使って広がりを持た 
せることができたら地域ブランドの創造として緩や かではあるが販路は拡大していくと考光る，加工業 としての売上金額としては決して大きいものではな いが，今後の取組に注目したい。

さらなる売り上げを伸ばすために蒋㴊身者だけで なく販路開拓の為, 東京, 大阪など都市部の百貨店 やスーパーの催事にも出店し少しずつ販路開拓を拡 大している.さて，漁業の活性化を促す上で地域の 研究が重要認識され始めているが真鯛の養殖と産地 再編についての研究論文は少ない。この蒋㴊の取組 に颃いては, 成功へ導いた絶対的な指導者がいなく ても地域力の認識が高まり，自分たちが次は何をす べきかを考光る思考力が生まれている.

蒋㴊の商品開発も大量に捨てられていた真鯛のア ラを商品として活用できないかと問題解決の為の商 品開発から始まった。 ともすると, 農山漁村の商品 開発は世の中が欲しがっているものを作るのではな く，自分たちが作りたいプロダクトアウトの商品が 多く，自画自賛で良い商品なのになぜ売れないのか となる。しかし, 商品開発の過程で多くの議論や異 業種の繋がりにより，マーケットの声に耳を傾けマ 一ケットインの商品開発に変わっていったからこそ, 売れる商品が出来上がった.

また，蒋㴊にはリーダーシップを取れる人がいな いにも関わらず，話し合いの中からアイディアが生 まれ形になっていった。

ぞちらも既存の研究で見逃されてきたものではな く，前者は既存の論文に記載が見えないことからマ ーケットインの考方方が定着していないものと考光 る. 後者はそらであれば, リーダーシップが無くて も産地再編ができる様々な地域での考察が，今後の 地域発展の分析の資料と成り得ると考光る.
注

1 地域の顕在する能力を高めながら潜在する地域力を掘り起こ して事業に生かし地域の人々すべての人に生かされ新たな地 域力を生み出し高めあっていく経営.

2 社会問題の解決を目的として収益事業に取り組む事業体のこ と. 社会的事業.

3 農林水産業者と中小企業者等が連携して行ら新たな商品・サ 一ビスの開発等の取組を支援する機関や団体に対しその事業 に要する経費の一部を助成することにより事業者の経営の向 上・改革や地域経済の活性化や雇用の創出につなげることを 目的としている制度.

4 ベシャメルソースとはホワイトソースの正式名で一般的には 牛乳，バタ一, 小麦粉で作るフランス料理に使われるンー ス.グラタンやコロッケなどにも使われる.

5 毎年開催される国際食品领料展で国内はもちろんアメリカ, フランス,イタリアなど約 3,000 社が集ら食の祭典. 国内外 のバイヤーが集まり商談も行われる.

6 企業が商品開発や生産を行う上で作り手の理論や都合を優先 させる方法.

7 社会のニーズを優先して顧客視点で商品の企画や開発を行い 提供していくこと.

\section{引用文献}

天野通子・佐藤友香・山尾政博（2015）「漁村女性グループに よる 6 次産業化の経営の自立化に対する要因分析」『農業 市場研究』23(4), 23-29.

小田切徳美（2011）『農山村再生の実践』農山漁村文化協会.

根岸裕孝（2014）『中小企業と地域づくり一社会経済構造転換 の中で—』鉱脈社.

農林水産省 (2013)「水産白書」(http://www.jfa.maff.go.jp/j/kikaku/ wpaper/h25_h/trend/1/t1_1_2_1.html）［2015 年 7 月 1 日］.

宮崎 猛（2015）「中山間地域に打けるコミュニティとビジネ スの持続可能性」『農業問題研究』50(4), 20-22. 